\title{
Benjamin Boysen
}

\section{Dostojevskij og melankolien}

\section{Dostojevskijs lidelsesevangelium}

Dostojevskij har altid enten fascineret eller vakt væmmelse ved sin uhyre eksponering af melankolikerens nydelse ved lidelsen. Hans værker er i allerhøjeste grad determineret og gennemsyret af en melankoli, der hér danner et intimt og passioneret partnerskab med den ortodokse og reaktionære kristendom. Protagonisterne lider næsten alle uden undtagelse af en eller anden form for melankoli, der enten ytrer sig som en nedtrykt glæde (en lidelsens egoisme), som en kompleks ambivalens mellem idealisering og devalorisering (både af sig selv og den anden) - den så velkendte ambivalens hos Dostojevskij, hvor kærlighed ender i had og omvendt - eller endelig som en sensuel glæde ved opløsningen af selvet (ved forbrydelsen, selvmordet eller epilepsien), hvor subjektets subversion resulterer i en 'oceanisk' og transcendent enhedsfølelse. Således er det langt fra tilfældigt, når en psykoanalytiker som Julia Kristeva ligefrem taler om hypostaseringen af lidelsen gennem Dostojevskijs værk som det essentielle træk ved forfatterens antropologi. ${ }^{1}$

\section{Hvad er melankoli?}

cur fletus dulcis sit miseris?

Augustin: Confessiones IV, 5

I artiklen Trauer und Melancholie (1917) forklarer Freud, hvorledes melankolien afviger væsentligt fra sorgen. Begge kan sjæleligt set beskrives ved en dybt smertelig nedtrykthed, hvor interessen for yderverdenen ophæves, og begge kan karakteriseres ved en manglende evne til enhver form for præstation; men hvor sorgen for den sorgramte er et ydre anliggende, der bliver sorgen for melankolikeren et indre: den sorgramte trækker sin libido væk fra det tabte objekt og forskyder den til et nyt, mens melankolikeren

1. Julia Kristeva: „On the Melancholic Imaginary«, in Shlomith Rimmon-Kenan (ed.): Discourse in Psychoanalysis and Literature, London 1987, p. 115. 
omvendt trækker libidoen tilbage i jeg'et. For den sorgramte er det således den ydre verden, der er blevet fattigere ved tabet, mens det for melankolikeren omvendt er den indre verden, der er blevet forarmet: „Ved sorgen er verden blevet fattig og tom, ved melankolien gælder dette jeg'et selv «. ${ }^{2}$ Essayet skelner overordnet set mellem melankolikerens egoistiske og narcissistiske selvbebrejdelser, hans ambivalente kærlighed og den sorgramtes bedrøvelige, men relativt uproblematiske optagethed af det tabte objekt. Freud definerer melankolikerens narcissisme som en regression til et infantilt stadie, hvor jeg'et bliver konstrueret af kadaverne fra dets sadistisk fortærede elskede: »Jeg'et vil gerne inkorporere dette objekt i sig og svarende til den orale eller kannibalistiske fase af libidoudviklingen sker det ved at fortære $\operatorname{det}$ «(MP 1, p. 229). Han beskriver endvidere melankolikerens begær efter at fortære det tabte objekt som en regression til et tidligere narcissistisk objektvalg: »Den narcissistiske identificering med objektet bliver da til en erstatning for kærlighedsbesætningen« (ibid.). I Freuds forestilling om melankoli, folder melankolikeren det tabte objekt ind i en indkapslet identifikation eller introjektion gennem en masochistisk transport af tabet til selvet. Melankolikerens libido er ikke forflyttet fra det tabte objekt til et andet, men bliver i stedet trukket tilbage til jeg'et selv vha. introjektionen, der kommer i stand ved jeg'ets identifikation med det tabte per se: »Objektets skygge faldt således på jeg'et, der nu kan bedømmes af en særlig instans på samme måde som et objekt, nemlig som det forladte objekt. På denne måde forvandlede objekttabet sig til et jegtab og konflikten mellem jeg'et og den elskede person til en splid mellem jegkritikken og det gennem identificeringen ændrede jeg« (MP 1, pp. 228-29). Når objektets skygge falder over jeg'et i melankolien, er det ikke objektet, men dets skygge som formørker jeg'et, dvs. en projektion eller repræsentation af objektet som tabt, der efterfølgende bliver introjekteret. Denne interioriseringens effekt er produceret uden for jeg'et; det er en skygge på jeg'et, snarere end det er en skygge i jeg'et. Anderledes sagt: Introjektionen påtvinger jeg'et forskelle inden for selvet, fordi det forudsætter en projektion, der henlægger en del af selvet til ydre fænomener. Denne skygge, som formørker jeg'et kommer fra den tabte anden - en anden, der slører forskellen mellem indre og ydre, det identiske og det fremmede.

Introjektionen installerer objektet på ny, dog med en betydelig ambivalens, fordi det simultant idealiserer det i en fantastisk resolution mod realiteten (hvorved tabet bliver afvist), og krænker og dødeliggør det gennem den symbolske optagelse af det via interioriseringen, der forudsætter tabet som fravær (hvorved tabet bliver bekræftet). Resultatet af denne narcissis-

2. Sigmund Freud: Metapsykologi 1, Kbh. 1983, p. 225. Herefter forkortet MP 1. 
tiske identificering bliver herved, at det tabte objekt inkorporeres i jeg'et som jeg-ideal, således at melankolikeren (til forskel fra den sorgramte, der anerkender adskillelsen fra det tabte) fornægter tabsoplevelsen ved at gøre sig til ét med det mistede objekt. Det betyder, at melankolikeren gør det ydre anliggende til et indre, hvorved skuepladsen for sorgens konflikt flyttes fra relationen til yderverdenen og introjekteres til jeg'et selv. Herved opnår melankolikeren en stor nydelse, idet han forvandler objektlibidoen (der er tilknyttet et ydre objekt) til en primær-narcissistisk objektbesætning, der slutteligt afstedkommer den så velkendte ambivalenskonflikt hos melankolikeren, som har sin årsag $i$, at kærligheden nu bliver ledsaget af destruktionstrang eller sadisme. Freud forklarer det besynderlige forhold således:

»Har kærligheden til objektet, der ikke kan opgives, når objektet selv opgives, søgt tilflugt i den narcissistiske identificering, så aktiveres hadet mod dette erstatningsobjekt, idet det forhåner og nedværdiger det samt påfører det lidelse, og i denne lidelse opnår det en sadistisk nydelse. Melankoliens selvpineri, der utvivlsomt er nydelsesbetonet, er lige som ved det tilsvarende tvangsneurotiske fænomen ensbetydende med tilfredsstillelsen af sadisme og hadtendenser, der gælder et objekt, og som på denne måde er blevet vendt mod individets egen person« (MP 1, p. 230; min kursivering.).

I forhold til yderverdenen konkretiserer melankolikerens ambivalenskonflikt sig altså primært ved en omskiftelighed i forhold til den anden (dvs. den person subjektet er stillet overfor) mellem hovmodig selvovervurdering og nedværdigende selvudslettelse. Dette afspejler, hvorledes melankolikerens indre verden (jeg'et) præges af en vekslen mellem nydelse (via den narcissistiske identifikation, dvs. sammensmeltning med det tabte objekt) og lidelse (ved erkendelsen af den absolutte adskillelse fra det mistede). Mht. sidstnævnte (nydelsen og lidelsen) iagttages det ganske fascinerende (eller frastødende) forhold, at disse bliver mere eller mindre uadskillelige hos melankolikeren.

Ambivalensen er som sagt udpræget i forhold til kærlighedsobjektet, som melankolikeren omslutter med en primær-narcissistisk kærlighed, og som han desuden udsætter for had og kærlighed på én gang, idet objektet på den ene side sikrer hans narcissistiske og introspektive symbiose med det hvorved tabserfaringen annulleres, - samtidig med at objektet på den anden side umuliggør denne tilstand, fordi det repræsenterer selve fraværet og tabet: »Ved melankolien opstår der således et utal af enkeltkampe omkring objektet, hvor had og kærlighed kæmper med hinanden, hadet for at løsrive libidoen fra objektet, kærligheden for at forsvare denne libidoposition mod angrebet« (MP 1, p. 235). Melankolikeren bliver, til forskel fra den sorg- 
ramte, ét med objektet ved stædigt at gentage en tvangspræget iværksættelse af dets tab, og objektet frelses på denne paradoksale måde, når det mistes, ligesom det bekræftes, idet det forkastes.

Dette besynderlige forhold har Julia Kristeva beskæftiget sig indgående med i sit arbejde med sorg og melankoli. Hun uddyber primær-narcissismens fortrin hos melankolikeren ud fra begrebet om et arkaisk, før-sprogligt, moderligt, symbiotisk og imaginært objekt, som subjektet længes efter at blive ét med. Sproget, og derved i særdeleshed bevidstheden - menneskets fødsel som et subjekt, der forstår sig selv ud fra sin forskellighed fra ydre objekter, - er, ifølge Kristeva, installeret gennem en negering af det sensuelle, kroppen og drifternes umiddelbare genstandsløshed: „Ofringen grundlægger symbolet samtidig med den symbolske orden, og dette 'første' symbol, som er offer for et mord, gør ikke andet end at repræsentere den strukturelle vold givet ved sprogets indtrængen som mord på soma'en, forvanskning af kroppen eller tilsnigelse af driften. $\star^{3}$ Herigennem vinder subjektet nok bevidsthed og autonomi, men denne tilvejebringelse er kommet i stand på bekostning af en enhedsfølelse, der bliver betegnet som det oprindelige, arkaiske, ikke-repræsentérbare, a-temporale, a-perceptionelle samt totalt nærværende, hvilket vil sige en tilstand før subjekt-objekt-konstellationen. Tilstanden før denne konstellation identificerer Kristeva psykogenetisk med mor-barn dyaden, hvorfor hun definerer melankolien som den "umulige sorg over det moderlige objekt «. ${ }^{4}$ Barnets tidlige enhed med moderen angiver, ifølge Kristeva, en sensuel og nydelsesbetonet, før-sproglig tilstand, som subjektet snart bliver berøvet i dets erhvervelse af sproget, der erstatter subjektets umiddelbare og sanselige selvnærvær med symboler. Symbolerne afløser tingene, hvorved subjektet som sprogligt væsen for bestandigt må se sig adskilt fra denne tidlige tilstand, hvor drifterne endnu ikke var hæmmede eller underlagt kontrol og censur. Det er tabet af denne tilstand, som melankolikeren begræder - idet han nu er begrænset, delt og betinget af repræsentationer, der spærrer for en umiddelbar adgang til verden.

Dette sammenfatter hun i begrebet om melankolikerens længsel efter $l a$ Chose, der betegnes som "noget ikke-repræsentérbart. $\|^{5}$ Begrebet har hun lånt fra en anden fransk psykoanalytiker, Jacques Lacan, for hvem det betegner en arkaisk grund, der går forud for enhver betydningsdannelse: „Denne Ding som Fremde, fremmed og sågar fjendtlig ved lejlighed, i alle tilfælde som det første udenfor [...] det er dette objekt, das Ding, for så vidt at det er

3. Julia Kristeva: La révolution du langage poétique, Paris 1985, p. 72.

4. Julia Kristeva: Soleil noir. Dépression et mélancolie, Paris 1987, p. 19. Herefter forkortet $S N$.

5. Op. cit., p. 23 
subjektets absolutte Anden, som det [subjektet] søger at genfinde. $\aleph^{6}$ Tingen er selve princippet for subjektets første møde med noget udvortes og fremmed, og går som sådant forud for enhver symbolsk repræsentation. Tingen er således en absolut Anden, der unddrager sig fremstilling inden for det timelige - dvs. sproget, det perceptuelle og fænomenale, - da den går forud for subjektets autonomi, som erhverves ved den sproglige tilegnelse. Lacan

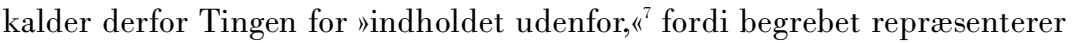
en arkaisk tilstand, hvor forskellen mellem udtryk og indhold endnu ikke er givet, idet der endnu ikke er givet nogen forskel mellem subjekt og objekt.

Når Kristeva hævder, at melankolikeren længes efter Tingen, betyder det derfor, at det er gennem jegopløsningen, at melankolikeren henter sin nydelse. Sidstnævnte må forstås inden for de rammer, som Freud afsatte i Jenseits des Lustprinzips, hvor dødsdrifter bestandigt truer med at subversere subjektet: »Dermed var den første drift opstået, driften mod at vende tilbage til det livløse ${ }^{8}{ }^{8}$ Ifølge Kristeva er denne konservative og livstruende drift således stærkt aktiv hos melankolikeren, hvor dødsdriften vender sig "mod jeg'et og genfinder et tabt paradis over et ikke-integreret jeg, uden andre og uden grænser, fantasme om en ukrænkelig fylde« $(S N$, p. 30). Således giver Kristeva Freud ret, når hun definerer melankolien som en narcissistisk regression; men hun supplerer vor forståelse heraf ved at insistere på den rolle, som dødsdriften spiller for melankolikerens begærs-fysiognomi. Hun finder, at melankolikerens erotisering af lidelsen har sin forklaring $i$, at han gennem den introverte nedtrykthed oplever en arkaisk nydelse derved, at han udsletter sig selv som subjekt for at indgå i en fuldkommen enhed med den absolutte Anden. Denne absolutte Anden repræsenterer almagt (atemporalitet), og subjektets forening hermed peger tilbage på symbiosen med moderen, hvor barnet ikke eksisterede som subjekt, men hvor det alligevel oplevede en salig enhedsfølelse med verden, samt omnipotens.

På denne måde er den melankolske diskurs intenst knyttet til en erotisering af lidelsen og døden, og i den melankolske forestilling er genstanden for kærligheden (og sorgen) altså i virkeligheden døden eller den døde, og hengivelsen hertil er både kvalfyldt og frydefuld. Derfor kan Kristeva hævde, at melankolikeren oplever depressionen »som en genforening med den arkaiske ikke-integration, der er lige så dødelig som den er jublende og oceanisk« $(S N$, p. 30). Denne oceaniske følelse er tæt forbundet med en følelse af en subversion af subjektet, dvs. ekstasen, hvor subjektet måske nok mister sig selv, men hvor det alligevel vinder en uendelig, lyksalig følelse af enhed med

6. Jacques Lacan: L'éthique de la psychanalyse, Paris 1986, p. 65. Herefter forkortet EP.

7. Op.cit., p. 67.

8. Sigmund Freud: Metapsykologi 2, Kbh. 1976, p. 46. Herefter forkortet MP 2. 
altet. Gåden om melankolikerens nydelse ved lidelsen er, at han ved at fremmane døden, det absolutte fravær og den totale meningsløshed, samtidig åbenbarer det paradisiske, fuldkomne og guddommelige: I den melankolske diskurs åbenbarer det absolutte fravær på paradoksal vis det absolutte nærvær - døden og lidelsen bliver hér blot andre ord for selve skønheden og evigheden, som vi skal se hos Dostojevskij.

\section{Lidelsens forrang}

menneskene forkyndte lidelsens skønhed: kun $i$

lidelsen lå livets mening.

Dostojevskij: Et latterligt menneskes drøm, 5

Ved gennemlæsningen af Dostojevskijs breve er det evident, at sorgen og lidelsen spillede en helt afgørende rolle i forfatterens tilværelse; af læsningen bliver det klart, at melankolien simpelthen udgjorde et fikspunkt for hans sjælelige engagement. Eksempelvis skriver han følgende fra Firenze til Maykov: »Hovedsagen er depressionen, og hvis jeg skulle forklare det yderligere, så ville jeg sige for meget. Men der er sådan en depression, at hvis jeg var alene, da tror jeg, at jeg ville blive syg af depression«. ${ }^{9}$ Mange år tidligere skriver han fra Skt. Petersborg til sin elskede bror, Mikhail: „Undertiden bliver jeg martret af overvældende depression «. ${ }^{10}$ Senere forklarer han ligeledes til broderen, at hans gennemgribende temperament altid har været melankolsk: „Du må ikke være sur på mig, for himmelens skyld, husk at jeg er ensom som en bortkastet sten; at jeg af natur altid har voret melankolsk, syg og overordentlig urolig«. ${ }^{11}$ Derudover skriver han fra Petersborg til Alexander Vrangel i forbindelse med sin første hustrus dødsfald, og forklarer hvordan deres samliv var ret ulykkeligt, men ligeledes intenst, for desto mere ulykkelige de var i deres samliv, desto tættere kom de hinanden: »Jeg vil blot sige, at selvom hende og jeg havde det absolut elendigt sammen (pga. hendes mærkelige, overfølsomme og morbidt fantastiske karakter) - så kunne vi ikke holde op med at elske hinanden; ja desto mere elendigt vi havde det, desto mere blev vi knyttet til hinanden «. ${ }^{12}$ Brevet peger på, hvorledes kærligheden for Dostojevskij i høj grad blev næret af identifikationen med den elskedes lidelser, og lidelsen viser sig altså som det egentlige ophav til kærligheden.

9. Complete Letters III, Ann Arbor 1990, p. 164, 27. maj 1869. Min kursivering.

10. Complete Letters I, Ann Arbor 1988, p. 150, januar-februar 1847.

11. Complete Letters I, p. 215, 21. august 1855. Min kursivering.

12. Complete Letters II, Ann Arbor 1989, p. 151, 31. marts 1865. 
Det er altså klart, at Dostojevskij i perioder oplevede heftige angreb af melankoli, hvilket forklarer og begrunder den massive og allestedsnærværende interesse for lidelsen, som gennemsyrer forfatterskabet. Dette er eksempelvis tydeligt i Dostojevskijs Optegnelser fra et kalderdyb, hvor der rettes en kraftig kritik mod de samtidige strømninger i Europa (positivismen, socialismen og utilitarismen), fordi de - ifølge protagonisten - ikke forstår lidelsens betydning for mennesket, og fordi de ikke forstår, at mennesket faktisk elsker lidelsen inderligt og betragter den som sin raison d'être. Således hævder kældermennesket:

„Måske elsker mennesket ikke blot velbefindendet, men også, og i ligeså høj grad, lidelsen? Og måske er lidelsen nøjagtig ligeså fordelagtig for ham som velbefindendet? At mennesket ofte $i$ frygtelig grad elsker lidelsen, er en kendsgerning [...] Imidlertid er jeg fast overbevist om, at mennesket aldrig vil give afkald på den sande lidelse, det vil sige - på ødelæggelsen og kaos. Og omendskønt jeg $i$ begyndelsen sagde, at jeg anså erkendelsen for menneskets største ulykke, véd jeg dog, at mennesket elsker den og ikke vil bytte den mod noget tankeligt velbefindende« (min kursivering). ${ }^{13}$

Påstanden om at mennesket ofte $i$ frygtelig grad elsker lidelsen udgør i Dostojevskijs forfatterskab en grundlæggende og dyb sandhed, hvis berettigelse værkerne hver og især lidenskabeligt søger at vidne om, idet udsagnet - ud over at påpege den irrationelle natur i mennesket - ligeledes vidner om en passioneret religiøs dimension i tilværelsen; lidelsen affødes hér af erkendelsen af, at det ikke er muligt at træde i direkte forbindelse med det absolutte eller ubetingede i den fænomenologisk erfarede verden, og lidelsen betegner således indsigten i den fuldstændige adskillelse fra det ubetingede - eller subjektets absolutte Anden. Uagtet subjektet véd, at det er adskilt fra det ubetingede - fordi det grundlæggende er determineret af det timelige forsøges denne erfaring omgået ved den lidenskabelige dyrkelse af lidelsen, der nivellerer den fænomenologisk erfarede verden og i stedet sætter den rene subjektivitet, hvor det absolutte anskues. Den melankolske hero lider hos Dostojevskij på denne måde under das unglückliche Bewußtsein - som det hedder hos Hegel, - dvs. under trangen til at forkaste det betingede (verden som lutter forfængelighed) til fordel for en ulykkelig trækken sig tilbage i sig selv, hvor blikket i stedet rettes mod det evige via fornægtelsen af den timelige verden. I forlængelse heraf er det sigende, at den særegne nydelse

13. Alle henvisninger til Dostojevskijs værker er fra Samlede Varker (overs. Ejnar Thomassen), København 1965-66, 22, p. 130. Herefter forkortet $S V$. 
ved lidelsen bliver karakteriseret med følgende ord i De ydmygede og de sårede, hvor en forhutlet lille pige, Nelly - »en forunderlig sygelig skønhed» ( $S V$ 17, p. 165), - standhaftig afviser omsorg: „Den gamle Ikhménjev havde ret - hun var såret, og hendes sår ville ikke læge; ved trods og mistillid til alle rev hun det op igen og igen, som om denne hendes smerte netop var hende en vellyst. Deri lå en lidelsens egoisme, om man kan udtrykke det sådan« ( $S V$ 17, p. 286). Denne lidelsens egoisme udtrykker netop det forhold, at pigen (som så mange af Dostojevskijs karakterer) fremstiller sig selv i et grundlæggende negativt forhold til omverdenen, som utrætteligt bliver fornægtet for omvendt at bekræfte lidelsens affekt, der rummer en arkaisk og regressiv vellyst, hvor det ydre objekt internaliseres og gøres til ét med jeg'et vha. fornægtelsen heraf.

Ambivalensen i lidelsens egoisme bliver tillige tydelig i følgende passage, hvor protagonisten i Et latterligt menneskes drøm forklarer: »Deres vanhelligede Jord blev mig endnu dyrebarere, end da den var et paradis, og det kun - fordi sorgen havde bredt sig over den. Oh - jeg har altid elsket sorgen og kummeren, dog kun for mig selv, for mig selv! «(SV 22, p. 400). Det latterlige menneske oplever i sin drøm om den parallelle verden, at paradiset først bliver virkeligt fuldkomment i det øjeblik, hvor det bliver ødelagt - for som det hedder i Prousts $\grave{A}$ la recherche du temps perdu: »det sande paradis er det paradis, som man har tabt «, ${ }^{14}-$ og lykken bliver for den narcissistisk/ melankolske fortæller først absolut i det øjeblik, hvor genstanden herfor er tilintetgjort for derefter at blive inkorporeret i jeg'et. Således bliver betingelserne for lykken i den ydre verden nok tabt, men omvendt opnår tabets genstand en reel intrapsykisk konkretisering, hvis tilsnit uomtvisteligt er narcissistisk.

Melankolien oscillerer altså mellem negativitet og affirmation, og selvom den narcissistiske interiorisering til dels er affirmativ, betyder det dog ikke, at jeg'et bliver forskånet for negativitetens rasen, idet jeg'et tværtimod fornægtes og søges udslettet pga. længslen efter det absolutte, hvilket selvmordet er det mest ekstreme eksempel på. Således mener ateisten, Kirillov, i De besatte, at han gennem selvmordet bliver Gud og oplever »et nuvorende evigt liv [...] øjeblikke, hvor tiden pludselig står stille og bliver evig« (SV 20, p. 239), ligesom selvmorderen i Selvmord og udødelighed, der i sin ateisme mener sig forment adgang til »altets harmoni« $(S V 22$, p. 295), hvorfor han slutteligt vælger at gå i døden: »som integrerende del af altets harmoni« $(S V$ 22, p. 297). Thanatos slutter sig altså til melankolikerens narcissistiske Eros og lader den skæbnesvangre negativitet råde såvel i den ydre - som den indre

14. Marcel Proust: À la recherche du temps perdu IV (Bibliothèque de la Pléiade), Paris 1989, p. 449. 
verden. Dostojevskij er da heller ikke blind over for disse subversive libidinøse kræfter, men fremhæver dem som sagt tværtimod, fx lader han i Idioten Lebedev (med sit heftige temperament) opsummere sagen således: »Ja-aavel! Selvødelæggelsesdriften og selvopholdelsesdriften behersker begge i lige grad menneskelivets love!« $(S V$ 8, p. 61).

\section{Ambivalensen hos Dostojevskij}

Odi et amo.

Catul LXXXV

Mikhail Bakhtin, som har leveret et af de vægtigste værker om Dostojevskij med sin Problems of Dostoevsky's Poetics, skriver indledningsvis heri: "Heltens bekræftelse (og forkastelse) af en andens 'jeg' - dette er temaet for Dostojevskijs værk «. ${ }^{15}$ Dette er ubestrideligt, idet heltene konstant svinger mellem negeren og bekræftelse af den anden (og sig selv), ${ }^{16}$ men i modsætning til Bakhtin - der belyser forholdet ud fra roman-teoretiske, dvs. mere tekniske overvejelser (teorien om den polyfone roman) - finder jeg, at forholdet snarere er et udtryk for den immanente understrøm af melankoli, der gennemløber forfatterskabet, nærmere betegnet den melankolske ambivalens. ${ }^{17}$

Denne melankolske vekselvirkning mellem had og kærlighed er tydelig i Dostojevskijs univers, ${ }^{18}$ hvor begge på besynderlig flyder sammen, og hvor begge synes at være den andens forudsætning, hvorfor kærligheden hos Dostojevskij som oftest kan betegnes som »la haine dans l'amour« ( $S V$ l, Ynglingen, p. 84) - eller som fyrst Mysjkin forfærdet udbryder til den mørke Ragózjin: »Din kærlighed kan man næppe skelne fra had « (SV, Idioten, p. 257). ${ }^{19}$ Hér er det ligeledes betegnende når dertil tilføjes, at Ragózjin rent faktisk ender med at slå sin elskede, Nastásja Fillípovna, ihjel ved roma-

15. Mikhail Bakhtin: Problems of Dostoevsky's Poetics, Mineapolis 1984, p.10.

16. René Girard har skrevet en spændende bog herom, Dostö̈evski du double à l'unité, i hvilken han hævder, at Dostojevskijs forfatterskab er ét langt forsøg på at overvinde denne infernalske kamp med den anden - hvor hovmodet og nedværdigelsen af sig selv begge er udtryk for selvovervurdering og narcissisme, - hvilket vil sige en overvindelse af denne ødelæggende ambivalens over for den anden.

17. Jf. Kristeva: Soleil noir, p. 196.

18. Den melankolske ambivalens kommer endvidere til udtryk i den dynamiske vekselvirkning mellem nihilisme og ortodoks kristendom, der begge synes at have deres kilde i mørk og irrationel drift: »I Dostojevskijs stora romaner finns en öppen och dramatisk dialog mellan aktiv nihilism och ortodox mystik. Lockelsen att bejaka den upproriska men urspårade sataniska viljan konfronteras med en oförenlig dragning till en sorts upplyst dårskap« Anders Olsson: Läsninger av Intet, Stockholm 2000, p. 101. 
nens afslutning. Omvendt er Nastásja ligeledes fuldkommen ambivalent i sine kærlighedsforhold, idet hun henholdsvis går fra Mysjkin til Ragózjin og vice versa; og når hun - på trods af sin store kærlighed til fyrsten - erklærer: "Hvad kan jeg andet end at fordærve dig?«(SV 7, Idioten, pp. 208-9), betyder det netop, at hendes bestemmelse i kærligheden ligeledes består i la haine dans l'amour, for som Ragózjin forklarer fyrsten: »Når hun flyr for dig, er det jo blot, fordi hun pludselig føler, hvor rasende hun elsker dig: hun holder ikke langere sin kcerlighed ud« (SV, Idioten, p. 261. Min kursivering).

Melankolikeren holder ikke sin kærlighed ud, fordi den narcissistiske jeg-libido herved bliver begrænset gennem objekt-libidoen, og melankolikeren nærer desuden had til kærlighedsobjektet (den anden), fordi denne blot åbenbarer det betingede i stedet for det absolutte (la Chose). Således betyder Nastásjas melankolske konstitution, at hendes lidenskab er mere imødekommende over for Ragózjin, idet hun véd, at han er i stand til at befri hende fra det betingede eller timelige derved, at han ødelægger hende og viser hende døden. Ragózjin er selv inde på dette: »Ja, det er netop grunden, hvorfor hun tager mig... at hun - hos - mig - er - sikker - på - kniven!« (op.cit., p. 260). ${ }^{20}$

Et lignende forhold optræder i De besatte, hvor Stavrogin og Mavrikij Nikilájevitsj begge bejler til Lisaveta Nikolájevna, der imidlertid - som Nastásja - er yderst ambivalent indstillet. Mavrikij forklarer: „Gennem hendes had til Dem, det oprigtigste og stærkeste had, luer hvert øjeblik kærligheden og... vanviddet frem... Den oprigtigste kærlighed, ja, - og et grænseløst vanvid. Derimod bryder gennem den oprigtige kærlighed hun føler for mig, hvert øjeblik hadet frem - et grænseløst had«(op.cit., p. 387). Kærlighed og

19. Således reflekterer titelpersonen, Arkadij Dolgorukij, i sine unge år over en fremtidig, imaginær kvinde: »Ja, jeg hadede denne kvinde, og dog elskede jeg hende allerede« ( $S V$ 1, Ynglingen, p. 92). Mod slutningen af romanen genkender han den samme ambivalente lidenskab hos sin fader: »Men gifter hun sig med ham, vil han dagen efter jage hende fra sig med pisken... ja, den slags forekommer. En sådan heftig og vild kærlighed er som et anfald [...] men næppe er den tilfredsstillet [...] og den modsatte følelse, afsky og had, lysten til at tilintetgøre, melder sig« (SV 2, Ynglingen, p. 265).

20. Begæret efter tilintetgørelsen er melankolikerens begær, og hos Dostojevskij kan det bl.a. aflæses i det forhold, at elskerne hyppigt foretager et umuligt objektvalg, hvilket $\mathrm{fx}$ kommer til udtryk i uendelige rivaliseringer om den elskede, hvor protagonisten som i Den unge vartinde eller De ydmygede og de sårede nærer kærlighed til en kvinde, som er tryllebunden af en anden mand, eller hvor de ligefrem konkurrerer med deres fædre om den elskede, således som det fx er tilfældet i Brødrene Karamazov og Ynglingen. Kærligheden til det umulige, dvs. kærligheden til den absolutte Anden, ytrer sig således enten i en uendelig vekslen mellem had og kærlighed, eller i kærligheden til et distanceret eller utilgængeligt kærlighedsobjekt à la manière de l'amour courtois. Girard peger da også i sin Dostö̈evski du double à l'unité på, at den sværmeriske og romantiske kærlighed til den utilgængelige hos Dostojevskij, dvs. kærligheden på afstand, i virkeligheden er udtryk for en narcissisme, der ikke formår at anerkende den anden, men som omvendt bestandigt søger at eliminere forholdet til den anden. 
had glider umærkeligt sammen, og Lisaveta elsker Stavrogin gennem sit had i den forstand, at hun ved at fornægte ham bekræfter sig selv - hvorved objekt-libido transformeres til jeg-libido, - og omvendt hader hun Mavrikij gennem sin kærlighed, idet narcissistisk jeg-libido forvandles til objektlibido. Men bevægelsen mellem det ydre og det indre, mellem had og kærlighed, er altså reversibel.

Ambivalensen mellem had og kærlighed kommer også til udtryk i ambivalensen mellem hovmod og selvudslettelse - bl.a. i Spilleren, hvor hovedpersonen definerer sig som slave i forhold til den stolte Polina, i hvem han er forelsket. Her forklarer han hende den særegne nydelse, som han føler ved at nedværdige sig over for hende: » $\mathrm{Nu}$, javist - det er mig en nydelse at være Deres slave. At stå på ydmygelsens og nedværdigelsens sidste trin - déri ligger virkelig en egen nydelse!« $(S V$ 18, p. 37). Men umiddelbart efter tilføjer han omvendt: »Ja, jeg vil dræbe Dem, ikke fordi jeg ikke længer elsker Dem eller af skinsyge, nej - simpelthen dræbe Dem, fordi jeg undertiden føler lyst til at sønderrive og fortare Dem« (op.cit., p. 39; min kursivering). På denne måde rummer melankolikerens forhold til den anden både slavens og herrens position - tillige med kærlighed og had - mellem hvilke han ustandseligt veksler. ${ }^{21}$ I den melankolske længsel efter a-temporalitet søger protagonisten i sin narcissistiske sorg egentlig at udslette den anden - enten ved selvudslettelse og hertil hørende transformation af den anden til subjektets absolutte Anden, eller gennem ophævelsen af sig selv til subjektets absolutte Anden gennem nedværdigelsen af den anden: »Polina må blive Gud i forhold til ham eller han må blive Gud i forhold til Polina - og Gud er den kosmiske nødvendigheds skæbnesvangre verdensskaber «. ${ }^{22}$ I slaveforholdet til den anden forkaster subjektet sit jeg til fordel for identifikationen med begærsobjektet, som selv herefter forkastes gennem internaliseringen. Lidenskaben hos Dostojevskij er sønderrivende og fortærende som i bakkanternes ekstase. En konkret illustration heraf er at finde i Den evige aegtemand, i hvilken hanrejen, Pavel Pávlovitsj, forsøger at myrde sin tidligere ven, Veltsjáninov (med hvem hans afdøde hustru bedrog ham), hvorefter Veltsjáninov gør sig følgende overvejelser: »Men også i går, da han gjorde mig sin kærlighedserklæring og ville 'udsone' sig med mig - elskede han mig da virkelig af hjertet? Ja, også i går, lige før sit morderanslag, elskede han mig elskede mig med forbitrelse. Og den kærlighed er den stærkeste af alle...«

21. Jf. Robert Louis Jackson, der ligeledes understreger ambivalensen i forholdet mellem Polina og spilleren, der begge har behov for hinanden samtidig med, at de hader hinanden: "Aleksey er hadet af Polina, men hun har brug for ham og drages mod ham. Polina er hadet af Aleksey, men han drages uafvendeligt mod hende $\mathrm{og}$ har brug for hende af dybere psykologiske årsager", The Art of Dostoevsky, New Jersey 1981, p. 217.

22. A. D. Savage: "Dostoevski: The Idea of The Gambler», in The Sewanee Review 58 (1950), p. 296. 
(SV 19, p. 153). Pavel er forbitret på sin gamle ven, fordi han lå i med hans afdøde hustru, men han elsker ham på den anden side og beundrer ham, idet Veltsjáninov er en succesrig dandy, der nyder stor social anerkendelse, mens han selv derimod næsten ingen agtelse nyder, da han gør en lidt latterlig figur, og idet han er 'den evige ægtemand', dvs. hanrej. Pavel identificerer sig med Veltsjáninov og elsker ham, idet denne er, hvad han selv gerne ville være, men omvendt føler han forbitrelse (over forsmædelsen) og had overfor dette imago, der betinger hans væren og som trælbinder ham. På denne måde ender ambivalensen mellem had og kærlighed i trangen til at sønderrive og fortære den elskede. ${ }^{23}$

Heltene hos Dostojevskij hader og elsker på én og samme tid, fordi de er determineret af melankolien, og idet de egentlig ikke formår at anerkende den anden, forbliver de fastlåst i en kamp på liv og død om enten at være herre eller slave. De elsker den anden for så vidt, at denne på narcissistisk vis spejler dem, - og samtidig hader de den anden for så vidt, at de derved mister deres uafhængighed, dvs. deres rene subjektivitet som bliver besudlet, da den må gå omvejen ad det udvortes for at udtrykkes; de elsker den anden for så vidt, at de gennem lidenskabens rasen opløfter denne til det absolutte men samtidig hader de den anden, fordi denne ikke formår at opfylde længslen efter det ubetingede, og fordi den anden i stedet overlader subjektet til det udvortes og timelige.

Heltene hos Dostojevskij søger desperat anerkendelsen fra de andre, men formår i deres narcissisme ikke at lade anerkendelsen være gensidig, da de som Alceste i Molières Le Misanthrope afviser fællesskabet: »je hais tous les hommes«, samtidig med at de fordrer genkendelse for deres ypperlighed: »Je veux qu'on me dinstingue«! ${ }^{24}$ Det bedste eksempel herpå er kældermennesket, der ud fra samme logik føler sig nødsaget til at tage til et selskab (til hvilket han i øvrigt ikke er inviteret), som nogle gamle klassekammerater holder, ikke fordi han bryder sig om dem, nej faktisk føler han den største væmmelse ved dem, men netop derfor føler han sig desto mere tvunget til at demonstrere for dem, at de ingen rolle spiller for ham! Paradokset består i følgende: Han har brug for dem for at vise, at han ikke har brug for dem, og

23. Fænomenet har Girard på glimrende vis analyseret i sit begreb om det mimetiske begær, hvor subjektet identificerer sig med en anden, hvis billede det begærer, og hvor det samtidig føler trang til at destruere den anden, fordi han gør ham ufri. Dette form for begær ser Girard bl.a. illustreret i beretninger om dobbeltgængere og i historierne om brodermord. Jf. Girards La violence et le sacré.

24. Molière: Euvres Complètes II (Bibliothèque de la Pléiade), Paris 1971, v. 118 og v. 63. Det er da heller ikke uinteressant, at Alceste i en stor udstrækning er melankolsk, hvilket vennen, Philinte, da også beskylder ham for at være, idet han bebrejder ham hans galdesyge (v. 166). Inden for datidens forestilling om de fire temperamenter var melankoli netop en sygdom, der skyldtes for meget galde (som bekendt har ordet melankoli sin oprindelse i det græske, af melanos, 'sort', og cholos, 'galde'). 
i sin narcissistiske bestræbelse efter uafhængighed af den anden som herre ender han i virkeligheden i ufrihed som slave, idet han konstant må søge bekræftelse af sig selv gennem fornægtelsen af de andre. Joseph Frank giver en lignende forklaring: »Kældermenneskets forfængelighed overbeviser ham om hans egen intellektuelle overlegenhed og han foragter alle; men når han erfarer, at han ikke kan slå sig til tåls uden deres anerkendelse af hans overlegenhed, da hader han de andre for deres ligegyldighed og knækker sammen i selvlede over sin ydmygende afhængighed. Dette er den ubønhørlige dialektik over en egoisme, der ikke kan glemme sig selv for et øjeblik, og som, idet den søger at fravriste anerkendelse fra verden, blot modtager antipati og fjendskab til gengæld «. ${ }^{25}$

Ødelæggelsen af billedet af jeg'et - således som det fremtræder for den andens øjne, - og profaneringen af den andens billede af jeg'et - for derved, at undslippe magten fra den andens bevidsthed, og herigennem at overvinde den andens imago af én for at nå frem til sit eget jeg, for jeg'ets skyld alene det er kældermenneskets bestræbelse med sine bekendelser. ${ }^{26}$ Derfor laver han bevidst sin tale om sig selv hæslig, fordi han hos sig selv vil ødelægge enhver trang til at fremtræde som et forbillede i andres øjne: »Jeg er ikke mere den helt for jer, som jeg før ville anses for - jeg er simpelthen en skidt karl, et subjekt. [...] I finder det modbydeligt at høre på min uværdige, min jammerlige og hæslige stønnen? Udmærket!...« (SV 22, Optegnelser fra et kcelderdyb, pp. 113-14).

Gennem nedværdigelsen af sig selv (en trang som er at iagttage overalt i Dostojevskijs værker) oplever melankolikeren en uhyre nydelse, idet han hermed frigør sig fra den andens magt, for som Freud konstaterer i sin Trauer und Melancholie, så er melankolikerens selvbebrejdelser i virkeligheden forklædte bebrejdelser rettet mod en anden end ham selv, hvilket i denne forbindelse vil sige, at den negativitet som melankolikeren vender mod jeg'et faktisk er rettet mod den anden. Negativiteten er således chiastisk: 'Jeg er slet, derfor er du også slet, men du ved det ikke, hvorfor jeg er, om end ikke bedre, så dog anderledes' - eller som Rousseau skriver i sine bekendelser: »jeg vover at tro, at jeg ikke er skabt som nogen af dem, der er til. Er jeg ikke bedre, er jeg $i$ det mindste anderledes ${ }^{27}{ }^{27}$

25. Joseph Frank: »Nihilism and Notes from Underground«, in The Sewanee Review 69 (1961), p. 26.

26. Jf. Bakhtins analyse af kældermenneskets negative forhold til den anden i Problems of Dostoevsky's Poetics, pp. 227-234.

27. Jean-Jacques Rousseau: Bekendelser 1, Kbh. 1966, p. 5. Min kursivering. 


\section{Via negativa: Forbrydelsens ætiologi}

I forlængelse af det foregående er det betegnende, at Dostojevskij gør temaet omkring forbrydelsen til genstand for en så enestående opmærksomhed, at det nærmest kun er Marquis de Sade eller Jean Gênet, der i denne henseende kan gøre ham rangen stridig. ${ }^{28}$ - I sit studium over Dostojevskij fremhæver Freud da også »Dostojevskijs meget stærke destruktionsdrift « ${ }^{29}$ Dostojevskij har pga. sit lidelsesevangelium en betydelig sympati for den sjæleligt 'sårede' forbryder, idet man hellere må være kold end lunken: „Jeg kender dine Gerninger, at du hverken er kold eller varm; gid du var kold eller varm! Derfor efterdi du er lunken og hverken varm eller kold, vil jeg udspy dig af min mund «. ${ }^{30}$ Hos Dostojevskij angiver den 'noble' forbryder-hero i forlængelse heraf den mystiske via negativa, ${ }^{31}$ hvor synden og lidelsen viser vej til frelsen og skønheden. ${ }^{32}$ Et eksempel på den 'ædle' forbryder-mentalitet er bl.a. at finde i Brødrene Karamazov, hvor Mitja - under overskriften 'En sjæl på lidelsens vej - Første martyrium’ - forklarer: »Men netop dette, at jeg har higet efter det ædle og alligevel kun begået skændigheder - netop dette, ser De, har pint mig hele mit liv igennem... jeg har været så at sige en martyr for det ædle, jeg har søgt det overalt med en lygte, med Diogenes' lygte, og samtidig har jeg hele livet igennem kun gjort det slette og gemene« ( $S V 4$, pp. 243-44; min kursivering.). De melankolske forbryder-heroer lider netop, fordi de er martyrer for det ædle. - Men hvad vil dette $i$ grunden sige?

Forbrydelsen er hos Dostojevskij for en stor dels vedkommende forbundet med en bitterhed eller rasen over tabet af det absolutte, hvilket faktisk udgør essensen af de berømte ord af Ivan: "Har mennesket ikke troen på sjælens udødelighed, findes der heller ingen dyd - alt er da tilladt! ( $S V$ II, 7, p. 117; min kursivering). Forbrydelsernes hærgen kan på denne måde anskues som en slags acting out af den metafysiske melankoli, idet bortfaldet af det absolutte medfører en forgiftning af sindet, en sorg så knugende så bitter, - at den resulterer i den rene destruktion. Mordet og forbrydelsen er altså intimt forbundet med frustrationen over det metafysiske tab af ide-

28. Af eksempler på det forbryderiske kan man fremhæve: Stavrogins voldtægt af den mindreårige, Matrjósja (De besatte); Kældermenneskets forbryderiske behandling af den prostituerede, Lisa (Optegnelser fra et kalderdyb); Smerdjakovs mord på patriarken, Karamazov (Brødrene Karamazov); Raskolnikovs mord på panterlånersken og hendes evnesvage søster (Raskolnikov); Ragózjins mord på Nastásja Fillípovna (Idioten); Forbryderne i fængselskolonien (Det døde hus); forbrydelsen mod Kristus (Den bodfcerdige); og slutteligt må selvmordet fremhæves, som er at finde overalt i forfatterskabet.

29. Sigmund Freud: "Dostojewski und die Vatertötung«, Gesammelte Werke XIV, Frankfurt am Main 1999, p. 401. Herefter forkortet $D V$.

30. [Der henvises (i parentes) til Johannes Åbenbaring, 3, 15-6. Henvisningen bør være mere udførlig/mindre indforstået og den skal herned i noten.] Motivet spiller en afgørende rolle i De besatte, hvor den hellige, Tíkhon, applicerer stedet på Stavrogin ( $S V 21$, p. 86). 
alitet, hvilket eksempelvis er klart i Ynglingen, hvor protagonisten, Arkadij Dolgorukij, reflekterer over Othello: »Versilov har engang sagt, at Othello ikke dræbte Desdemona og derefter sig selv af skinsyge, men fordi man havde berøvet ham hans ideal...« (SV 1, p. 293). Refleksionerne over Shakespeares tragedie viser sig at have samme gyldighed i Dostojevskijs værk, hvor bl.a. Ragózjin på lignende vis slår Nastásja ihjel, fordi hans ophævelse af hende til subjektets absolutte Anden viser sig at være uholdbar: hun kan ikke opfylde hans fordringer om idealitet, hvorfor han i fortvivlelse herover tilintetgør hende. En anden af forbryder-heroerne, nemlig Stavrogin, lider også under sorgen over den tabte forbindelse til det absolutte, og er ligeledes en martyr for det cedle, hvilket i hvert fald er moderens, Varvarja Petrovnais, opfattelse. Hun siger om sin søn:

»Det er en stolthed, der for tidligt er blevet forgiftet, der er slået om i bitter ironi, og som nu kun finder sig til rette i en 'komisk tilværelse' Deres udtryk var slående. Det er med ét ord prins Henrik, som Deres far engang så træffende kaldte ham, og det ville have været fuldkommen rigtigt, hvis det ikke mindede endnu mere om Hamlet, hvad i hvert fald jeg for min part synes, det gør« (SV 20, De besatte, p. 191).

31. Begrebet via negativa er glimrende eksemplificeret ved Saulus, som indædt fornægtede Kristus og sammenbidt forfulgte de kristne, men som imidlertid mødte Gud, der i et strålende lys fra himlen spurgte ham: „Saul! Saul! hvorfor fornægter du mig? « Apostlenes Gerninger 9, 4[bør skrives helt ud, ikke i parentes]. Derefter mistede han synet i tre dage, fik det tilbage, blev døbt og fyldtes af Helligånden, hvorved vejen, der leder bort fra Gud, alligevel $\mathrm{i}$ sidste ende viste sig at lede hen til den guddommelige nåde. I digtningen af Juan de la Cruz (1542-1591) foreligger endvidere et andet illustrativt eksempel på den negative vej; i et digt som 'Noche obscura del alma' beskrives det, hvorledes sjælen afsværger og taber verden af syne til fordel for en intim genoplevelse af Kristi korsfæstelse - for derigennem at hædre ham og opnå en mystisk forening med det guddommelige. Begrebet var centralt for den såkaldt negative teologi, der florerede i middelalderen, og som understreger, at den guddommelige længsel efter at indgå enhed med Gud fordrer subjektets tilintetgørelse, der dog på paradoksal vis opfattes som en umådelig og grænseløs oplevelse. I den negative teologi er udslettelsen af selvet over for den absolutte Anden et helt central tema, fx hos den kristne mystiker, Meister Eckhart (1260-1327), der understreger den negative vej fra det værende til intetheden som vejen til Gud, der i sin umiddelbare umådelighed selv er intet: "Og i dette Ene skal vi evigt synke ned fra Noget til Intet», Predigten III, Stuttgart 1976, 83, p. 448. Slutteligt kan det nævnes, at begrebet spiller en meget central rolle i det anonyme middelalderskrift, The Cloud of Unknowing, hvori forestillingen om at blive ét med det guddommelige tilsvarende konkretiseres i en selv-tilintetgørende virksomhed: "Lad dette Overalt og dette Noget være til fordel for dette Intetsteds og dette Intet. Nær ingen bekymringer, såfremt dine sanser ikke har nogen forståelse for dette Intet; af denne grund elsker jeg det blot desto mere«, The Cloud of Unknowing, Cambridge 1986, LXVIII. Selvdestruktionen over for en almægtig Anden forekommer altså yderst attråværdig i denne doktrin om den melankolske nydelse ved hengivelsen til den personificerede intethed. 
Umiddelbart herefter tilføjer hun, at sønnen lider under »ironiens dæmon« (op.cit., p. 192), hvilket er ganske betegnende for den 'ædle' forbryderlogik hos Dostojevskij, hvor ironiens dæemon hjælper den ulykkelige og melankolske bevidsthed til at nivellere verden for derved at kunne trække sig tilbage i ren subjektivitet, - ganske som den unge prins Hamlet: »O God, I could be bounded in a nutshell and count / myself a king of infinite space «. ${ }^{33}$ Hertil kommenterer moderens gode ven, Stefan Trofímovitsj: "jo slettere et menneske lever eller jo mere forkuet et folk er, des mere hårdnakket drømmer de om belønning i et fremtidens paradis« (op. cit., p. 192), hvorved temaet om via negativa igen bliver åbenbart.

En anden dimension af forbrydelsen som via negativa knytter sig til den melankolske trang til selvdestruktion, som i virkeligheden udgør forbryderheltenes mest essentielle bevæggrund for forbrydelserne; den udadrettede negativitet er således en projektion af den selvdestruktion, som hos melankolikeren er genstand for en uhyre nydelse. Således hævder Dostojevskij, at den »russiske Mefisto« er rede til (mht. den optimale skændighed): »for dette ene triumferende sekunds skyld, [at] tilintetgøre sig selv for evigt« ( $S V$ 22, Den bodfardige, p. 240), og i Det døde hus forklares forbryderens morderrus tillige ud fra trangen til selvdestruktion:

"han drives nu afsted som af en vild lyst til at trodse alle love, al autoritet og ret, han nyder denne tøjlesløse, ingen grænser følende frihedstummel, nyder sit eget hjertes svimlen og rivende fald ned i den bundløse rædsel. Under alt dette ved han, at en skrækkelig straf venter ham. Hans tilstand kan måske sammenlignes med den følelse, hvormed et menneske, stående på et højt tårn, bøjer sig ud og føler sig lokket af dybet under sine fødder, indtil han fristes til at styrte sig hovedkulds ud i det: et eneste spring - og alt er til ende!« (SV 16, p. 129).

Sammenligningen er sigende, fordi den viser, at den primære nydelse ved forbrydelsen består i gennemlevelsen af dunkle og subliminale dødsdrifter, igennem hvilke forbryderen på ny føler sig forenet med den regressive og arkaiske urtilstand, der kendetegnes som ikke-repræsentérbar, a-temporal, a-perceptionel samt totalt nærværende (dvs. la Chose). Melankolikerens anden verden, dvs. manien eller nydelsen, forklarer Freud tentativt ved, at

32. Jf. Knud Hansen, som gør sig følgende overvejelse om Dostojevskij: »Hvad synderen søger i det onde er ikke alene det jordiske livs hele vældighed, men også, og ofte uden at han selv ved det, 'den skjulte port der åbner ham vejen til det evige'. I viljen til forbrydelse kan der være en hemmelig hunger efter anger og genfødsel, efter moralsk fornyelse. Ubevidst higer synderen efter at komme til at angre«, Dostojevskij, København 1973, pp. 360-1.

33. William Shakespeare: Hamlet, II, ii, 254-5, London 1997 (The Arden Shakespeare, ed. Harold Jenkins). 
overjeg'et enten er blevet tilsidesat eller smeltet sammen med jeg'et: "jeg'et befinder sig i en salig rustilstand, der triumferer, som om over-jeg'et havde mistet al kraft eller var flydt sammen med jeg' et «. ${ }^{34}$

Desuden er forbryderen hos Dostojevskij oftest kendetegnet ved melankoli, hvilket i høj grad gør sig gældende hos en af de mest markante forbryder-heroer, nemlig Raskolnikov, som både lider under én afgrundsdyb sjæelekval, ${ }^{35}$ og som dernæst i høj grad er determineret af den melankolske ambivalens. ${ }^{36}$ I sin samtale med Sonja bliver det bl.a. tydeligt, at aggressionen og mordet rettet mod pantelånersken ikke blot var motiveret af romantiske Übermensch-aspirationer, ${ }^{37}$ men tillige havde sit ophav i driften til selvdestruktion, der gennem forbrydelsen blev projiceret udad: „Har jeg da virkelig slået den gamle ihjel? Mig selv har jeg slået ihjel, ikke den gamle! Med det slag gjorde jeg det af med mig selv for livet!..." (SV 15, Raskolnikov V, 4, p. 145; min kursivering). Raskolnikov udgør hos Dostojevskij paradigmet på via negativa, idet han - som i biblens historie om Saulus fornægter og forfølger Kristi ånd, bliver lutret, for til sidst at modtage nåden og kærligheden i et kommende jordisk paradis med Sonja, for som hun siger: "Tage lidelsen på dig og ved den forløse dig - det skal du!« (ibid.). Undersøgelsesdommeren, Porfyrij Petrovitsj, er inde på noget af det samme, idet han spår Raskolnikov, at han en dag vil tage lidelsen på sig: "pludselig, en skønne dag, vil De komme og aflægge tilståelsen! Og De vil en time forud selv ikke vide af, at tilståelsen er i anmarch. De vil komme på den tanke at ‘tage lidelsen på Dem’ [...] Thi lidelsen, Rodin Románovitsj, er noget ophøjet [...] i lidelsen ligger en dyb idé« (op.cit., p. 188).

I Dostojevskijs roman bliver det blotlagt, hvorledes forbryderens (Raskolnikovs) destruktive handlinger udadtil, på samme tid raser med uformindsket brutalitet indadtil: nok fornægter forbryderen den anden, men samtidig viser det sig, at han fornægter sig selv, således at han omgiver sig med lutter negativitet, hvis endemål er at fremmane den absolutte subjektivitet, hvor han som Gud kan sige: »jeg er den, som jeg er«. ${ }^{38}$ Men den

34. Sigmund Freud: Nye forelcesninger om psykoanalysen, Kbh. 1959, p. 52.

35. Raskolnikov bekræfter selv dette: »jeg er så trist, så trist til mode!« (SV 14, Raskolnikov, p. 203); hans moder karakteriserer ligeledes ham og søsteren, Dunja, som melankolske: "begge er I tunge af sind, begge dystre og heftige, begge hovmodige og højsindede..." (op.cit., p. 250).

36. Som Nastásja i Idioten holder han ikke langere sin karlighed ud, og den bliver derfor på samme vis blandet med et intenst had; karligheden bliver for ham ophavet til forbrydelsen: "Oh, om jeg dog stod helt ene, om ingen elskede mig, og jeg selv aldrig havde elsket noget menneske! Så havde alt dette ikke været! [...] Oh, jeg hader dem, hvor jeg hader dem!«, $S V 15$ pp. 248-9. Jf. tillige: »Mor og søster - hvor har jeg elsket jer! Hvorfor hader jeg dem nu? Ja, jeg hader dem, hader dem fysisk: jeg tåler dem ikke i min nærhed ...«SV 14, p. 286.

37. Jf. Raskolnikovs stærke identifikation med Napoleon: „Ser du: jeg ville være en Napoleon derfor slog jeg ihjel...«SV 14, p. 140. 
ekstatiske genforening med la Chose - dvs. det absolutte nærvær, hvor forskelle ikke eksisterer, - som han iværksætter gennem de grænseoverskridende og subversive excesser, fordrer subjektets tilintetgørelse.

Forbrydelsernes betydning åbenbares altså i de kristne mystikeres forestilling om via negativa, hvor subjektets subversion i 'Noche obscura del alma’ udløser sammensmeltningen med Gud; forbryder-heroerne hos Dostojevskij foregriber den melankolske forestilling om den eskatologiske og apokalyptiske tid, hvor destruktion og affirmation - fødsel og død - er det samme; en tid hvor den absolutte negativitet åbenbarer det absolutte nærvær, dvs. dét øjeblik i hvilket, der ikke mere skal gives Tid. ${ }^{39}$

\section{Den melankolske a-temporalitet: Tiden skal ikke være mere}

Fyrst Mysjkin, hvis tilfælde udgør et af de mest interessante eksempler på melankoli hos Dostojevskij, forklarer i Idioten, hvorledes han undertiden blev heftigt angrebet af tungsind under sit kurophold i Schweiz: »Ja, jeg husker det - jeg var knuget af et uudholdeligt tungsind; jeg havde ofte kunnet græde. [...] Det frygteligste var, at jeg følte alt omkring mig så fremmed. Denne følelse af fremmedhed ville, det stod mig ganske klart, efterhånden dræbe mig« ( $S V$ 7, p. 74). Følelsen af tungsind og fremmedhed knytter sig for Mysjkin specielt til den skønne naturoplevelse, hvor angsten og sorgen ledsager oplevelsen af skønhed: "Altid, når jeg første gang ser en sådan natur, bliver jeg mørk og trist i sindet, og en vis uro kommer over mig; den er skøn, ja, og samtidig urovækkende $\ll^{40}$ Modsat naturbeskuerens interesseløse behag ved naturoplevelsen hos Kant, hvor overensstemmelsen mellem naturens og sjælens skønhed udgør kernen i den skønne naturoplevelse, og hvor det absolutte derigennem fornemmes, ${ }^{41}$ bliver skønheden hos Dostojevskij (som den majestætiske natur åbenbarer) ikke ledsaget af følelsen af harmoni og metafysisk enhed, - nej den bliver snarere efterfulgt af følelsen af en uhyre ensomhed, adskillelse, fremmedgørelse og angst:

38. Anden Mosebog 3,14.

39. Johannes Åbenbaring 10,6.

40. Op.. cit., p. 76. I det hele taget er oplevelsen af lykke og skønhed intimt forbundet med oplevelsen af fremmedhed og sorg hos fyrsten, hvilket i særdeles udgør essensen af den melankolske beskaffenhed: »altid, når han følte sig løftet i en stærk følelse af glæde, meldte samtidig også det dybe vemod sig, han vidste selv ikke hvorfor«, SV 7, Idioten, p. 46.

41. Jf. Kritik der Urteilskraft $§ 59 \& \$ 42$. 
»i sådanne øjeblikke kunne uroen i mig vokse til en beklemmende angst. [...] himmelrummet skcrende blåt og stilheden - oh den frygtelige stilhed! Så kunne det synes en, som om der kaldtes på en et eller andet sted $i$ det fjerne, og jeg tænkte ofte, at hvis man vedblev at gå lige frem for sig, gå og gå - til den linie, hvor Himmel og Jord mødes, - så ville man dér finde gådens løsning: dér ville der straks åbenbare sig et nyt liv, et liv tusind gange storkere og mere berusende end her «. ${ }^{42}$

Følelsen af angst og vemod, som den overvældende skønhedsoplevelse udløser, bliver derefter tæt knyttet til følelsen af et intenst nærvær, der er stærkt nydelsesbetonet. Stillet over for naturen føler fyrsten sig fremmedgjort i forhold til det absolutte, la Chose, dvs. tingen bag fænomenernes tilsynekomst, men aner omvendt muligheden for en forening hermed, hvor Himmel og Jord mødes, dvs. hvor adskillelsen mellem essens og eksistens ikke eksisterer, hvor verden, således som den bliver forstået gennem menneskets symbol-dannende aktivitet, er blevet udslettet.

I en af Nietzsches aforismer fra Morgenröte bliver dette forhold - dvs. den skønne naturs latente grusomhed mod beskueren - på glimrende vis formuleret: "O hav! O aften! I er slemme læremestre! I lærer menneskene at ophøre med at være mennesker! $\star^{43}$ Betragtningen kan med en vis ret siges at være betegnende for opfattelsen af det skønne, sådan som den præsenterer sig i Dostojevskijs værk; således hævder selvmorderen i Selvmord og udødelighed $\mathrm{fx}$, at det er oplevelsen af naturens skønhed og harmoni, der er årsagen til hans selvvalgte endeligt:

"Da min spørgen efter lykken får det svar, min egen erkendelse af naturen kan give, nemlig: at jeg ikke kan nå til nogen lykke uden som integrerende del af altets harmoni - en harmoni, som jeg ikke forstår og aldrig vil være i stand til at forstå - [...] så har jeg kun at tilintetgøre mig selv«(SV 22, pp. 297-8).

Da selvmorderen i sin absolutte fordring definerer lykken som en tilstand, man kun kan opnå som integrerende del af altets harmoni, må han begå selvmord for at blive forenet med la Chose, der som Lacan siger »har vakt

42. Op. cit., p. 78. Min kursivering. Når fyrsten forklarer, hvorledes det midt i den majestætiske skønhed synes en, som om der kaldtes på en et eller andet sted $i$ det fjerne, så indikerer han, hvordan personifikationen af det absolutte (L'Autre eller la Chose) forfører ham til at vende opmærksomheden væk fra det denne- til det hinsidige uden for verden. Skønheden bliver for melankolikeren tegnet på verdens afgrundsdybe forgængelighed, bag hvilken det absolutte skjuler sig som i Dürers berømte træsnit, Melancholia I.

43. Friedrich Nietzsche: Werke I, V, § 423 (ed. Karl Schlechta), Darmstadt 1997, p. 1219. 
mit begær efter døden «. ${ }^{44}$ Gennem selvmordet (eller nydelsen ved lidelsen) bliver adskillelsen mellem subjektet og la Chose udslettet.

Centralt i melankolikernes sorg over det skønne står fremmedgørelsen, dvs. følelsen af at stå uden for det skønne eller det i-sig-selv-nærværende. Det er gennem denne fornemmelse, at de føler en dyb adskillelse eller forskel fra det værende, og det er denne forskel som de søger at overvinde vha. negativitetens rasen. Genstanden for melankolikerens sorg er altså, som det er blevet antydet, erkendelsen af, at han står uden for det værende qua sin eksistens (jf. etymologien: ek-sistere), og at han ikke er del af altets integrerende harmoni, idet han erfarer at hans grundlæggende måde at være til på sine qua non forudsætter en forskel fra det værende. Han erfarer, hvad Heidegger kalder for den ontologiske differens (die ontologische Differenz), dvs. forskellen mellem det værende (das seindes) og væren (Sein) ${ }^{45}$ og denne forskel søger han at annullere via sorgens og negativitetens nivelleren. Den ontologiske differens er det vitale i konstitueringen af mennesket som subjekt, og den udgør forudsætningen for mennesket som bevidstheds-entitet. Men i kraft af, at mennesket konstitueres som subjekt, mister det samtidig følelsen af absolut nærvær med verden (tilstanden før Freuds sekundcerproces $){ }^{46}$ fordi negativiteten fra da af altid vil ledsage det via repræsentationerne, som udgør bevidsthedens spillerum. Melankolikeren kan grundlæggende ikke acceptere denne negativitet, og det melankolske projekt består derfor i ophævelsen af den ontologiske differens, og han søger derfor lidelsen (i alliancen med dødsdriftens) gennem forbrydelsen, sygdommen, depressionen eller selvmordet, hvorigennem sekundærprocessens arbejde ødelægges, og hvorved han oplever en før-sproglig genforening, der både er dødelig og vidunderlig.

Den ek-statiske og orgastiske tilstand, som melankolikeren oplever gennem dødsdriftens virksomhed, er udtalt i Dostojevskijs værk, hvor den ofte kommer til udtryk i sygdomsoplevelser. I Den unge vartinde kan man for eksempel fremhæve den melankolske Ordynov, som »intet [følte] uden denne kvalfulde og vellystige vé i sit bryst« $(S V 10$, p. 74), og som i sin syg-

44. EP, p. 101 (se note 6).

45. Omkring den ontologiske differens, jf. eksempelvis Heidegger: Identität und Differenz Pfullingen 1959.

46. Sekundærprocessen (Sekundärvorgang) er hos Freud stærkt knyttet til realitetsprincippet, og markerer overgangen fra primærprocessen og nydelsesprincippet, hvor subjektet er afmægtigt overladt til omverdenens omsorg, og hvor det hverken besidder forestillinger eller sprog, men hvor det til gengæld ikke oplever den adskillelse og det fravær som realitetsprincippet udløser, da denne primært fungerer via udsættelse af driftsopfyldelse. Gennem sekundæroplevelsen bliver subjektet et bemestrende subjekt, men taber derved den arkaiske nydelse ved den uhæmmede driftsudlevelse (jf. Freuds diskussion af fort-da legen i Jenseits des Lustprinzips samt Lacans udlægning heraf i »Fonction et champ de la parole et du langage en psychanalyse«, som er at finde i skriftsamlingen Écrits fra 1966). 
doms febervildelse erfarede, hvordan den grænseløse lidelse åbenbarer en uudholdelig lykke:

"samtidig mærkede han tydeligt, hvorledes han på ny mistede bevidstheden, hvorledes et uigennemtrængeligt, bundløst mørke åbnede sig for ham - ja, han troede endog at høre sit eget skrig, det skrig af kval og fortvivlelse, hvormed han styrtede i denne afgrund... Men så kom der også øjeblikke af en overvældende, en næsten uudholdelig lykke sådanne øjeblikke, i hvilke hele denne menneskelige livskraft stiger som i et krampagtigt sæt og ligesom løfter mennesket op i en højere sfære« ( $S V$ 10, pp. 84-85).

Den intense oplevelse af depression og angst er altså stærkt forbundet med en intens følelse af lykke og metafysisk enhed, og hos Dostojevskij er førstnævnte den uomgængelige forudsætning for sidstnævnte; det eskatologiske er hos Dostojevskij tæt knyttet til forestillingen om uendelig lyksalighed.

Undergangsmotivet hos Dostojevskij er nok mest udpræget i Idioten, hvor Hans Holbeins maleri af Den døde Kristus $i$ Graven spiller en central rolle som det ultimative udtryk for melankolien. Mysjkin ser en kopi af billedet hos Ragózjin, der hævder, at han elsker at se på billedet, hvortil fyrsten udbryder: „Du elsker at se på det billede! Men dette billede kan jo betage et menneske hver gnist af tro!« ( $S V 7$, p. 264). Hippolyt giver senere i romanen følgende beskrivelse af billedet:

"Når man betragter dette billede, må naturen forekomme én som et vældigt, ubønhørligt og stumt uhyre, eller rigtigere, ja, langt rigtigere, skønt det måske lyder lidt mærkeligt - som en kæmpemæssig maskine af moderne konstruktion, der uden mening eller hensigt griber dette herlige, kostbare uvurderlige væsen, knuser det og maler dets legeme mellem sine stålhjul, dette væsen, som alene er hele naturen og alle dens love, ja, hele jordkloden værd - jordkloden, der måske kun er skabt ene og alene, for at dette væsen kunne udvikle sig på den! Ja, det er netop denne forestilling om en mørk, brutal og meningsløs magt, en alt betvingende, alt opslugende magt som bringes til udtryk i dette billede og uvilkårligt meddeler sig til beskueren« (SV 8, pp. 99-100).

Forestillingen om den døde guddom er det mest smertelige og kvalfulde, men rummer alligevel (eller snarere: netop derfor) en intens skønhed, idet menneske-guden Kristus for et øjeblik er menneskene lig og deler deres lidelse. Kristus - der i sin niende time på korset udbrød: „Min Gud! Min 
Gud! hvorfor har du forladt mig? «, ${ }^{47}$ og som i Nervals »Le Christ aux oliviers» afmægtigt udbryder: »hvis jeg dør, da vil alt dø!« - bliver gennem døden ét med menneskene, ${ }^{48}$ og tager således del i menneskets skæbne, hvorved menneskelivet bliver transcenderet. Således hedder det i det Nye Testamente: „Vi bleve altsaa begravne med ham ved Daaben til Døden, for at, ligesom Kristus blev oprejst fra de døde ved Faderens Herlighed, saaledes ogsaa vi skulle vandre $i$ et nyt Levned. Thi ere vi blevne sammenvoksede med ham ved hans Døds Afbillede, skulle vi dog ogsaa være det ved hans Opstandelses «. ${ }^{49} \mathrm{Gud}$ må blive dødelig for en stund, for at det dødelige menneske kan blive Gud lig. Denne identifikation mellem Gud og menneske kan med stor ret betegnes som kærlighed, og kærligheden - der som bekendt »er stærk som Døden ${ }^{50}$ - forener mennesket og Gud i døden, hvorved identifikationen, og den heraf følgende ekstreme følelse af lidelse med Den døde Kristus i Graven, bliver forlenet med en uhyre følelse af ømhed og kærlighed i sam-

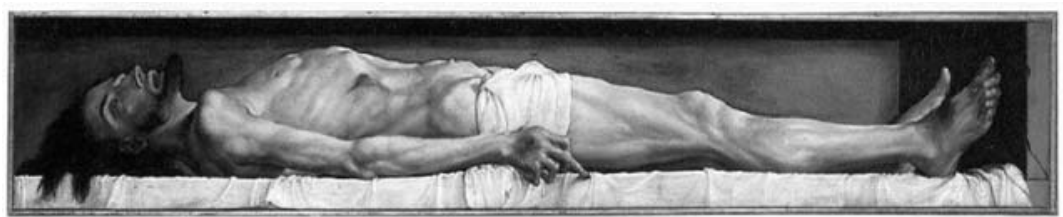

Hans Holbein Den Yngre: Den Døde Kristus i Graven (1522). Kunstmuseum Basel

mensmeltningen med det absolutte. Kærligheden er hos Dostojevskij drevet til det yderste, hvilket vil sige til døden: »kærlighedens bevægelse er, drevet til sit yderste, en dødsbevægelse $«{ }^{51}$ Forestillingen om den døde Kristus rummer en sublim skønhed, fordi den som billede på den uendelige lidelse (eller rettere det eskatologiske) rummer den overskridelse af verden, dvs. den primære affekt, som dødsdriftens virksomhed udløser.

Selvom forestillingen om den totale meningsløshed er forbundet med den størst mulige kval og lidelse, rummer den dog omvendt en følelse af ufattelig intensitet, skønhed og nærvær. Dette udgør essensen af Mysjkins skildring af den dødsdømtes sidste minutter, når han for den unge Adelaide beskriver, hvorledes hun som motiv for sit maleri kunne male det sidste øjeblik før guillotineringen - og som eksempel på et sådant billede henviser han faktisk også til Hans Holbeins Den døde Kristus i Graven. Fyrsten forklarer først, hvordan den dødsdømte i sine sidste minutter må lide usigeligt: „Dog

47. Markusevangeliet 15,34.

48. Gérard de Nerval: Euvres Complètes I (Bibliothèque de la Pléiade), Paris 1989.

49. Paulus brev til romerne, 6, 4-56.

50. Salomons Højsang 8,6.

51. George Bataille: L'érotisme, Paris 1995 (org. 1957), p.. 48. Herefter forkortet E. 
- den største, den frygteligste pinsel er sikkert ikke de legemlige sår; nej, det frygteligste af alt er den klare og sikre bevidsthed, at om en time, derefter om ti minutter, så blot et halvt minut, så nu - nu, i dette øjeblik... vil sjælen forlade dit legeme, og du vil i det samme ophøre med at være et menneske. [...] Netop i det øjeblik, da man bøjer hovedet ind under kniven og derpå hører, hvorledes den oppefra klirrer og glider ned mod halsen - netop denne fjerdedel af et sekund må være det skrækkeligste af alt!« (SV 7, Idioten, p. 32). Uagtet øjeblikket er det mest kvalfulde og frygtelige, fordi døden og tilintetgørelsen er nært forestående, så er øjeblikket omvendt på paradoksal vis uhyre intenst og nærværende - fyrsten tilføjer nemlig: „Dog disse fem minutter synes ham en uendelighed, en uhyre rigdom« (op.cit., p. 79), og hævder videre, at det: »har forekommet den dømte på dette korte stykke vej, som har han endnu haft en uendelighed af liv foran sig« (op.cit., p. 84). Det absolutte fravær (døden) ækvivalerer altså det absolutte nærvær (livets ekstase). Mysjkin afslutter sin beretning om den dødsdømte ved at sammenkæde dødsøjeblikket med en mystisk og religiøs følelse af omnipotens og omnipræsens, idet: »han strækker sine læber hen [mod præstens krucifiks], og mens han gør det, ser han alt og - véd alt« (op.cit., p. 86).

Der er således noget ophøjet og smukt (nydelsesbetonet) ved øjeblikket foran døden, og situationen passer glimrende på Batailles definition af begrebet om erotismen, der betegnes som »Anerkendelsen af livet lige indtil døden« $(E$, p. 17). Bataille undersøger i sin bog, hvorledes grænsesituationer (som orgasme, forbrydelse, ofring, ekstase, etc.), hvor døden eller bevidsthedens fravær er nærværende, samtidig udløser en uhyre jeg-følelse, der opleves som en overvældende forbundethed med verdensaltet. Hos Bataille er erotismen en grundlæggende trang af erotisk tilsnit hos mennesket til som i ekstasen - at miste sig selv: »i erotismen mister jeg mig« (E, p. 37). Den dødsdømte strækker i hengivelse sine læber hen mod krucifikset lige før henrettelsen, og der udgår således en umådelig kærlighed og ømhed fra mødet med døden hos Dostojevskij.

Disse eskatologiske oplevelser af ekstatisk skønhed knytter sig hos Dostojevskij specielt til epilepsien, som i nærværende sammenhæng må fremhæves som den melankolske sygdom par exellence. ${ }^{52}$ Den kendteste epileptiker hos Dostojevskij, fyrst Mysjkin, oplever anfaldene således: »I disse

52. Jf. Freud, der læser epilepsien symptomatisk: „Det er nu overordentligt sandsynligt, at den såkaldte epilepsi blot var et symptom for hans neurose«, $D V$, p. 402 (se note 29), samt Elizabeth Dalton, der argumenterer for, at Dostojevskij selv opfattede sygdommen sjæleligt: "Hvad der end måtte være det organiske grundlag for hans epilepsi, så syntes han altid at opfatte den fortrinsvis som et psykisk og et moralsk fænomen. I hans præsentation af Myshkins epilepsi er der sandt at sige ingen interesse i den som værende organisk; den bliver næsten fuldt og holdent behandlet som en mental og sjælelig tilstand «, Unconscious structure in The Idiot, New Jersey 1979, p. 126. 
øjeblikke tidobledes som i et lyn hans følelse af liv, af alskabningens væsen og hans eget selv. [...] al kval og ophidselse, al hans tvivl og uro opløste sig ligesom i en højere ro, i en ro fuld af klar, harmonisk glæde og håb, fuld af visdom og erkendelse« ( $S V 7$, p. 272). Den paradisiske enhed med subjektets absolutte Anden opnås altså gennem anfaldet, hvor alle forskelle forsvinder, og hvor den narcissistiske enhed, som melankolikeren længes efter, endvidere er tydelig, idet epilepsien opleves som: »en ufattelig løftelse af hans selverkendelse [...] en i det uhyre potenseret, i højeste umiddelbar følelse af hans eget jeg« (op.cit., p. 273).

Kirillov, den melankolske selvmorder, oplever ligeledes samme ekstatiske enheds-følelse med det absolutte: „Der gives sekunder, højst fem, seks ad gangen, i hvilke man pludselig har en følelse af at gå op i den evige, i alle tings fuldkomne harmoni. [...] Men jeg siger, at det er en følelse, som et menneske i sin jordiske skikkelse ikke kan udholde: enten må han forvandles fysisk eller dø» (SV 21, De besatte, p. 238, min kursivering). Hertil advarer Sjatov ham: »Tag dem i agt, Kirillov, jeg har hørt, at epileptiske anfald begynder netop således« (op.cit., pp. 238-9).

Når Kirillov om denne ekstatiske tilstand siger, at man enten må forvandles fysisk eller dø, så indikerer det for det første, at tilstanden er karakteriseret ved en destruktion af subjektet (som er forbundet med en uhørt nydelse), og for det andet forklarer det, hvorfor han senere begår selvmord: i sin længsel efter det absolutte forestiller han sig, at han gennem den ultimative selvdestruktion (selvmordet) bliver forenet hermed, idet han således mener at blive Gud. Kirillovs fremstilling af hans forventninger til selvmordet ligger da også tæt op ad hans beskrivelse af de ekstatiske (epileptiske) oplevelser. I sit studie over det abjektale noterer Kristeva tilsvarende en passant, at Kirilovs ekstatiske selvmordsdiskurs sidestiller det absolutte tab af menneskelighed og mening med en hinsidig skønhed og religiøs harmoni (bagom subjektets død): „Abjektionen oscillerer altså mellem forsvindingen af al mening og af al menneskelighed, forbrændt som i flammerne fra en brand, og ekstasen af et jeg, der - idet det har tabt sin Anden og sine objekter - berører harmoniens topmål sammen med det Forjættede Land netop i dette selvmords øjeblik «. ${ }^{53}$

I beskrivelsen af Mysjkins epileptiske anfald (just som Ragózjin prøver at myrde ham) hedder det: „Så var det pludselig, som åbnede der sig noget for hans blik: et ubeskriveligt, blændende lys tændtes i hans indre og gennemstrålede hele hans sjæl. [...] Så slukkedes brat hans bevidsthed, og alt forsvandt i dybt mørke« (SV 7, Idioten, p. 283). Mysjkin mister bevidstheden og sin menneskelighed, hvilket yderligere bliver fremhævet af skriget:

53. Julia Kristeva: Pouvoirs de l'horreur, Paris 1983, p. 25. 
"Som bekendt indtræder sådanne anfald ganske pludseligt [...] og et skrig, hvis radsel ingen forestilling fatter, og som ikke kan lignes ved noget andet, trænger frem af brystet; $i$ dette skrig forsvinder ligesom alt menneskeligt, og en iagttager er det umuligt at forestille sig, at det virkeligt er dette menneske foran ham som skriger. Ja, det synes, som hidrører skriget fra et helt andet væesen, fra et uhyre, som skjuler sig i menneskets indre» (op.cit., p. 283; min kursivering).

I det epileptiske anfald, hvorigennem fyrsten oplever en paradisisk følelse af enhed med verdensaltet, bliver destruktive og tilintetgørende kræfter afsløret, dvs. kræfter hvis virke står i et antagonistisk forhold til den menneskelige tilværelse. I den melankolske ekstase bliver alle forskelle udslettet til fordel for ét a-temporalt nu, hvor hverken fortid eller fremtid eksisterer, for som Mysjkin (med Apokalypsen in mente) siger: »I dette nu tror jeg at begribe hint vældige ord om, at tiden ikke skal være mere« (op.cit., p. 273). For fyrsten er Apokalypsens ord om udslettelsen af tiden udtryk for »skønhed og salighed«, samt »livets højeste syntese« (op.cit., pp. 272-3), mens de omvendt for den døende Hippolyt snarere forekommer at være ironiske eller sardoniske:

" - Var det ikke bedst at vente til i morgen? - afbrød fyrsten ham nølende.

- I morgen 'vil tiden ikke være mere', som det hedder i Apokalypsen, svarede Hippolyt med et krampagtigt smil«(SV8, p. 71).

Hippolyts bemærkning peger på, at der bagom den ekstatiske følelse af enhed med det evige, alle tings fuldkomne harmoni, snarere er tale om dødens åbenbaring, den fuldkomne tilintetgørelse af selvet, dvs. en eskatologi uden apokalypse.

En lignende ambivalens over for dødens eventuelle, vederkvægende transcendens finder vi et andet sted i Brødrene Karamazov, hvori Fader Zosimas død vækker stort påstyr, fordi hans lig udspreder en uudholdelig ligstank, der står i skærende kontrast til den skønhed, som døden ifølge Fader Paisij skulle rumme: "Du skal fryde dig, ikke græde. Véd vi da ikke, at denne dag er den største af alle hans dage? Hvor er han nu, i denne stund? Tænk blot på det!« (SV 4, p. 63). Ambivalensen mht. til det hinsidige er eklatant og er i sin dobbelthed helt parallelt med Hippolyts spydige udbrud.

Længslen efter alle tings fuldkomne og evige harmoni deler Andrei Petrovitsj (Ynglingen) med Stavrogin (De besatte). De har begge en drøm, i hvilken de befinder sig i Claude Lorrains Acis og Galethea (som de i øvrigt begge kalder 'Guldalderen'), og begge oplever heri en usigelig lykkefølelse: 
»En lykkefølelse, jeg aldrig før har kendt, fyldte mit bryst næsten indtil smerte, en løftende kærlighed til hele menneskeheden... Det var allerede blevet aften, ind ad vinduet, mellem geranierne i vindueskarmen, faldt aftensolens sidste strålebundter og badede mig i gyldent lys« ( $S V$ 2, Ynglingen, p. 206).

»Hér har den europæiske menneskehed tænkt sig sin vugge, hér udspilledes mytologiens første hændelser, hér var dens jordiske paradis. [...] Solen, der badede disse øer og havet omkring dem i sine strålers varmende lys, glædede sig hér over sine herlige børn. [...] Følelsen af en ukendt lykke fyldte mit hjerte indtil det smertende vemod." (SV 21, De besatte, pp. 102-3).

I maleriet finder de begge et udtryk for den fuldkomne lykke, hvor kærligheden er allestedsnærværende, og hvor følelsen af enhed med det absolutte er ubetinget. Maleriet illustrerer drømmen om tiden, der er ophørt med at være til, dvs. en oprindelig, samt arkaisk tid, som befinder sig uden for verden, og hvor mennesket er ubesmittet af negativitet og død, og hvor fravær samt forskelle ikke eksisterer. Men drømmen om det absolutte nærvær, dvs. forestillingen om den ubetingede lyksalighed, lader sig imidlertid ikke opfylde, idet Polyfemos' melankolske brøl - »el melancólico vocío« - runger over den fortryllende scene. ${ }^{54}$ Derudover bliver drømmen om lyksaligheden uden for tid og rum simpelthen udslettet ved mytens udgang, idet kyklopen i sin skinsyge slynger et klippestykke efter Acis, som knuser ham helt og aldeles (jf. Ovids Metamorfoser XIII, 884).

For Andrei glider drømmen om den ultimative lykke på lignende vis over i forestillingen om den største gru og skræk: $\mathrm{Og}$ da, min ven - da blev denne solnedgang på den europæiske menneskeheds forste dag, som jeg havde oplevet i drømme, for mig, da jeg vågnede, straks til solnedgangen på den europæiske menneskeheds sidste dag! Dengang var det, som genlød luften over Europa af dødsklokkernes klang« (SV 2, Ynglingen, p. 207; min kursivering). $\mathrm{Og}$ Stavrogin kan heller ikke fastholde forestillingen om guldalderen, der i stedet glider over til billedet af Matrjósja, som er den mindreårige han voldtog, og som derefter begik selvmord: »Jeg lukkede øjnene igen som for at tvinge drømmen tilbage; men pludselig så jeg midt i det klare lys et lille bevægeligt punkt, der for mine øjne langsomt tog ganske tydelig form af en bittelille rød edderkop. [...] Jeg så hende for mig. (Oh, havde det blot været

54. Don Luis de y Argote Góngora: Fábula de Polifemo y Galatea VI, 2, in Obras completas I, Madrid 2000. 
et virkeligt 'syn', i vågen tilstand!) - jeg så Matrjósja for mig, indfalden, med feberglinsende øjne, nøjagtig som da hun dengang stod på tærskelen til mit værelse, rystede på hovedet og hævede sin lille knytnæve mod mig. Aldrig endnu havde jeg folt noget så kvalfuldt!«(SV 21 De besatte, pp. 102-3; min

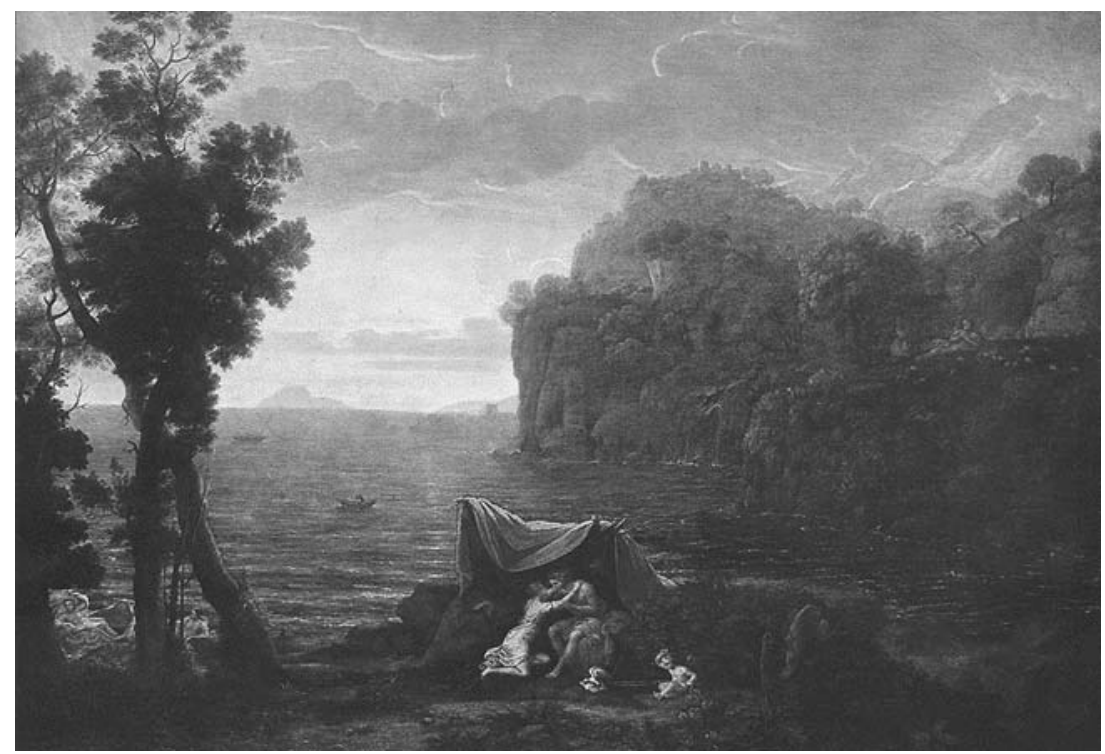

Claude LORRAin: Acis og Galathea (1657). Dresdner Gemäldegalerie

kursivering). I melankolien glider det absolutte fravær altså over i det absolutte nærvær og omvendt, fordi det absolutte nærvær fordrer subjektets subversion. De ekstatiske tilstande hos Dostojevskij afslører dødsdriften som den egentlige drivkraft i åbenbaringen af skønheden, saligheden og enheden med alle tings harmoni. Den 'oceaniske' følelse er den affekt, som bliver udløst ved subjektets regressive og arkaiske forening med la Chose, hvilket fordrer jeg'ets udslettelse:

"Oprindelig indeholder Jeg'et det hele, senere skiller det en omverden ud af sig. Vor nuværende Jeg-følelse er således kun den indskrumpede rest af en mere omfattende - ja, af en mere altomfattende - følelse, hvortil der svarede en mere inderlig forbindelse mellem Jeg og omverden. Hvis vi kan tillade os at gå ud fra, at denne primære Jeg-følelse i større eller mindre udstrækning er blevet opretholdt i mange menneskers sjæleliv, hvor den altså optræder som en slags modstykke til den modne alders snævrere og mere skarpt afgrænsede Jeg-følelse og side om side med denne, vil det forestillingsindhold, der skulle svare til den, netop være 
den ubegrænsethed og den forbundethed med Altet, som min ven beskrev som en 'oceanisk' følelse. ${ }^{55}$

Det paradoksale består i, at den regressive følelse af enhed og forbindelse med verdensaltet i melankolien bliver etableret ved en vedholdende negation af verden - den indre såvel som den ydre. Herved smelter den melankolske nydelseserfaring sammen med den religiøse salighedsfølelse, og i begge tilfælde synes sorgen og timeligheden at blive tilintetgjort til fordel for det transcendente og uendelige gennem det eskatologiske: $0 \mathrm{~g}$ han skal aftørre hver Taare af deres Øjne, og Døden skal ikke være mere, ej heller Sorg, ej heller Skrig, ej heller Pine skal være mere; thi det forrige er veget bort «. ${ }^{56}$ Døden og lidelsen forsvinder i det øjeblik, at verden og tiden ophører med at eksistere, hvilket spejler kristendommens bud om at forsage verden, og hvor en stærk aggression rettes mod det timelige jeg: „Elsker ikke Verden, ikke heller de Ting som ere i Verden! Dersom nogen elsker Verden, er Faderens Kærlighed ikke i ham «. ${ }^{57} \mathrm{I}$ det hele taget hviler kristendommen på en uhyre erotisering af lidelsen og døden, og det essentielle i kærligheden til Gud er således identifikationen med Kristi død, som er negativitetens fikspunkt, hvorfra vor forening med Gud bliver muliggjort. Således forklarer Bernard de Clairvaux (1090-1153) i sin Liber de diligendo deo: »den som erindrer Kristi død, og som følger hans eksempel ved at dræbe sit jordiske liv, han vil have evigt liv: Idet vi deltager i Kristi lidelser, hersker vi med ham «. ${ }^{58}$ Den platoniske sublimerings destruktivitet når således sin mest ekstreme gennemførelse i kristendommen, hvor ideen om agapê i høj grad affødes af dogmet om, at vi gennem døden dræber døden: »Thi den, som vil frelse sit Liv, skal miste det; men den, som mister sit Liv for min Skyld, skal bjærge det « . Dostojevskijs samtidige og ligesindede, Søren Kierkegaard, definerer tillige, i sin Indøvelse i Christendom, det kristne sindelag som »Fordring til at afdøe fra Verden, til at opgive det Jordiske, til Selvfornægtelse «, ${ }^{60}$ og han forklarer videre, hvorledes det kristne kærlighedsbud består i en betingelsesløs selvdestruktion samt $\mathrm{i}$ en given afkald på verden, sig selv og den anden: „Først naar Du er afdød fra Selviskheden i Dig og derved fra Verden, saa Du ikke elsker Verden, ei heller de Ting som ere i Verden, end ikke selvisk elsker et Menneske - naar Du i Kjerlighed til Gud har lært at hade Dig selv: først da kan der være Tale om den Kjerlighed, som er den christelige «. ${ }^{61}$

55. Sigmund Freud: Kulturens byrde, Kbh. 1987, p. 11.

56. Johannes Åabenbaring 21, 4 .

57. Johannes første brev, 2, 15.

58. IV, 11, Migne (ed): Patrologia latina 182, Turnhout, Belgien 1966.

59. Matthæus-evangeliet 16, 25.

60. Søren Kierkegaard: Samlede Varker 16, Kbh. 1962-64, p. 234. 
Fremfor at vende sig mod sorgarbejdet, dvs. anerkende de uundgåelige tab, som timeligheden medfører, søger melankolien i sin alliance med kristendommen snarere at forkaste denne grunderfaring for i stedet at bedøve sjælen og bevidstheden med en uendelig negativitet, der nok medfører et afkald af alt og alle, men som alligevel sikrer, at sorgen, lidelsen og døden ikke længere synes at være, og som tillige giver en uhyre nydelse via dødsdrifternes tilfredsstillelse. Frem for at forholde sig til nødvendigheden, dvs. det timelige, ved at vende sig mod nøden, nære omsorg for nøden, vender de russiske melankolikere hos Dostojevskij sig hellere væk fra verden, for (som Antigone) at eksilere sig i en narcissistisk gravhvælving.

\section{Konklusion}

Som vi har set er forholdet mellem lidelsen og nydelsen, død og ekstase, tæt forbundne hos Dostojevskij, og de intime forbindelser mellem nydelse og lidelse er altså ikke modsatrettede, men repræsenterer snarere en oscilleren mellem to poler: subjektets trang til at transcendere timeligheden og erkendelsen af projektets umulighed. Endvidere er skønheden hos Dostojevskij intenst forbundet med lidelsen og døden, og den angiver muligheden for en transcendens af den fænomenale tilværelse, men viser sig i virkeligheden at være et facies hippocratia, som forfører Dostojevskijs helte til selvdestruktion.

Man kan uden overraskelse konstatere, at Dostojevskijs lidelsesevangelium i høj grad er bestemmende for hans moralske indstilling, en indstilling der i høj grad kan anfægtes. ${ }^{62}$ I Den bodfordige hylder Dostojevskij det russiske folks trang til lidelsen, idet han skriver: »Jeg tror, at det russiske folks oprindelige, dybeste åndelige trang er trangen til at lide; det er en evig og umættelig trang, der ytrer sig overalt og i alt« ( $S V$ 22, p. 236). Når Dostojevskij overalt hylder trangen til lidelse, forklarer det, hvorfor han i en så utiltalende grad er ortodokst indstillet over for enhver tale om social forandring. Lidelsens priviligerede rolle er altså ikke blot bestemt ud fra den ortodokse kristendom, som mange i deres ærbødighed overfor Dostojevskij ellers er tilbøjelige til at mene, ${ }^{63}$ nej den er faktisk mere bestemt ud fra den melankolske konstitution, og jeg vil hævde, at den ortodokse kristendom snarere er et symptom på melankolien end omvendt.

61. Til Selvprøvelse, Samtiden anbefalet III, Søren Kierkegaard: Samlede Varker 17, Kbh. 1962-64, p. 120.

62. Jf. »Det mest angribelige er etikeren hos Dostojevskij», $D V$, p. 399 (se note 29). 
I artiklen »Om Europa og det russiske folk« i tidsskriftet Vremja, distancerer Dostojevskij sig kraftigt fra de socialistiske strømninger i Europa, hvis slagord om lighed, frihed og broderskab han finder hul. I stedet for socialismens idé om socialt broderskab sætter han idéen om selvopofrelse, som han finder udgør broderskabets sande væsen: „Forstå mig ret: en frivillig, fuldkommen bevidst, ikke af nogen - eller noget som helst fremtvungen selvopofring til held for alle, er efter min mening tegnet på personlighedens højeste udvikling, dens højeste magt, dens største selvbeherskelse, tegnet på den personlige viljes største frihed. At give sit liv frivilligt hen for alle, at dø døden for alle, på korset eller på bålet, kan kun den, som har udviklet sin personlighed til den højeste styrke og frihed « $(S V 22, \mathrm{IV}$, p. 71). Dostojevskijs teologiske moral viser sig altså, at være tæt forbundet med trangen til lidelse og selvdestruktion, og bærer vidnesbyrd om Nietzsches påstand om, at den kristne moral snarere er livsforsagende end livsforherligende.

Den overvældende rolle som melankolien spiller for Dostojevskijs liv og værk forklarer glimrende, hvorfor han er så reaktionær, idet han foretrækker erotismen frem for arbejdet, hvilket vil sige, at han foretrækker den enkeltes sakrale og voldsomme inderlighed, samt subjektivitetens uendelige negativitet, frem for fællesskabets progressive virksomhed, der er udvortes og profan. I erotismen har man et inderligt forhold til lidelsen, idet man hér

63. Et eksempel på en sådan ærbødighed, dvs. modvilje over for kritisk stillingtagen til Dostojevskij, kan man finde hos højskolemanden, Knud Hansen, som skriver: „I sin kritik af det bestående er Dostojevskij ikke sjældent både mere skarpsindig og mere uforsonlig end Marx«, Hansen: Dostojevskij, p.. 399 (se note 32). Nuvel, dette er der ingen, der bestrider, men hvor Marx opfordrede til, at filosofien snarere skulle søge at ændre verden end at beskrive den, der nøjes Dostojevskij med at beskrive de sociale problemer i stedet for at opfordre til ændringer af samfundsindretningen, og agiterer tværtimod passioneret for en bibeholdelse af det bestående - uagtet han har et skarpt og kritisk blik for den sociale nød og elendighed. Han vender sig energisk mod sociale tiltag, fordi man hér ønsker at ændre forholdene, således at folket i betydelig mindre grad lider, hvilket virker voldsomt provokerende på Dostojevskij, idet han mener, at en sådan bestræbelse eliminerer menneskets 'åndelige' (dvs. kristelige) side, fordi folks oprindelige, dybeste åndelige trang er trangen til at lide. (Jf. i øvrigt Rousseau, der i sin Contract social påpeger, hvorledes kristendommen er uegnet til at styre samfundet, fordi det er i modstrid med kristendommens væsen at foretage nogen aktiv, samfundsorienteret virksomhed, fordi den er en lidelsesreligion, som snarere opfordrer til resignation end engagement. Denne holdning deles endvidere af John Stuart Mill, der i sin On Liberty fremfører en parallel kritik.). Årsagen til Dostojevskijs reaktionære holdning skyldes, at han finder, at lidelsen udgør menneskets eneste sjælelige håb for frelse, hvorfor det er typisk at ateisternes og nihilisternes manglende tro på Gud skyldes, at de ikke kan acceptere lidelsen, idet den indebærer en accept af den guddommelige orden. Således udbryder Ivan: »Jeg vil ikke have, at moderen omfavner bødlen, der lod hendes dreng sønderrive af hunde. [...] Hun kan, om hun vil, tilgive for sit vedkommende [...] Men sit til døde jagede, sønderrevne barns lidelser - dem har hun ingen ret til at tilgive morderen [...] Findes der i hele verden et væsen, en magt, som kunne tilgive her, som havde ret til at tilgive? Jeg vil ikke vide af nogen harmoni, af kærlighed til menneskene akcepterer jeg den ikke«, $S V$ 3, Brødrene Karamazov, p. 334. Kan kærligheden til menneskene forenes med kærligheden til Gud? Spørgsmålet synes langt fra afklaret i russerens forfatterskab. 
nydelsesfuldt mister sig selv - at dø døden for alle, på korset eller på bålet, - mens man i arbejdet netop ikke mister sig selv, idet man på hegeliansk vis hæmmer begæret gennem afgivelsen af sin umiddelbarhed. Den reaktionære indstilling skyldes altså, at Dostojevskij qua melankoliker (eller ortodoks troende) sætter det uformindskede begær op som vejviser for menneskelig interaktion, idet: „Begæret forbeholder sig den rene negering af genstandene for derigennem at sikre sig den ublandede selvfølelse «, ${ }^{64}$ hvorimod han vægrer sig mod arbejdet, fordi: "Arbejdet derimod er hæmmet begær, forpligtet forsvinden«. Gennem martyriet eller den folkelige trang til lidelse, hvorfra den kristne grund har sit udspring, bliver den samfundsmæssige etik et spørgsmål om, hvorvidt man er rede til at acceptere nydelsen ved lidelsen. Idet man tillader en regulering af begæret, dvs. en regulering af den rene negering og den ublandede selvfølelse gennem arbejdet, så giver man afkald på den nydelse (som er narcissistisk og destruktiv, og som ikke formår at anerkende den anden), der via dyrkelsen af lidelsen (ifølge Dostojevskij) afføder en solidarisk folkesjæl. ${ }^{65}$ Men denne solidaritet er en falsk solidaritet, fordi dens udgangspunkt er det uhæmmede begær, som forkaster og nivellerer det udvortes til fordel for det indvortes (subjektiviteten), hvor bevidstheden i sin dvælen ved sig selv afskriver det profane fællesskab; derudover er solidariteten falsk, fordi den forkaster arbejdet, der er hæmmet begær, fordi subjektet må aflægge en del af sin subjektivitet i det udvortes for at opnå anerkendelsen fra 'der Andere'.

64. G. W. F. Hegel: Phänomenologie des Geistes, IV, A, Hamburg 1988, p. 135.

65. I modsætning til denne moralske holdning står Tolstoj, der fremhæver arbejdets essentielle betydning for fællesskabet menneskene imellem. Arbejdet er det, som binder menneskene sammen, og som derigennem giver den enkelte en meningsfuld tilværelse: »Hvad bør en mand gøre? Også han må arbejde for sin eksistens, ligesom dyrene gør, men med den fordel, at han vil gå til grunde, hvis han gør det alene, for han må arbejde for en tilværelse, ikke bare for sig selv, men for alle. Og når han gør det, da er jeg ret sikker på, at han er lykkelig og at hans liv er meningsfuldt«, Tolstoj: A Confession, London 1987, XI, p. 61. Der gives ikke noget alternativ til arbejdet, som går forud for enhver meningsskabende virksomhed, og som ene tilbyder den enkelte lykke, idet man gennem arbejdet nok hæmmer sin egen subjektivitet og selvudfoldelse, men alligevel transcenderer sig selv ved at blive en del af det universelle og almenmenneskelige. Det er gennem arbejdet, at ensomheden og fremmedgørelsen bliver overvundet, som det fx er tilfældet med den sky og melankolske godsejer, Leóvin, der føler sig fremmed og isoleret fra sine omgivelser, men som ved at tage del i sine undergivnes arbejde, for første gang oplever den lykke og mening med tilværelsen, som hidtil har været ham nægtet: „Nogle af de selv samme Bønder, der havde disputeret mest med ham om Høet, de Bønder, han havde gjort Fortræd, eller som havde villet bedrage ham, disse selv samme Bønder, havde hilst glædestraalende paa ham, og det var aabenbart, at de hverken nærede eller kunde nære nogen som helst uvenlig Tanke imod ham, og at de paa ingen Maade fortrød, ja ikke engang mindedes, at de havde villet bedrage ham. Alt var druknet i det glade Fællesarbejdes Hav. Vorherre havde skænket en Dag, Vorherre havde skænket Kræfter. Baade Dagen og Kræfterne helligedes Arbejdet, og i selve Arbejdet laa Belønningen«, Tolstoj: Anna Karenina I, Kbh. 1928, p. 366. Men denne samhørighed og selvovervindelse gennem arbejdet fordrer anerkendelsen af den anden, hvilket ikke forekommer muligt i Dostojevskijs univers. 
Men denne forkastelse af arbejdet er ikke blot en negering af bestræbelserne på at forandre samfundet, men tillige en forkastelse af selve sorgarbejdet, hvor man i solidaritet med de levende efterhånden giver afkald på de døde og det fraværende, frem for at værge om dem i sjælens narcissistiske krypt. Gennem (sorg)arbejdet opgiver man nok at tillægge døden et forløsende og transcendent indhold, men til gengæld vinder tilværelsen på denne side af livet desto mere værdi og nærvær: "sorgarbejdet er ikke et arbejde blandt andre. Det er selve arbejdet, arbejdet $\mathrm{i}$ almindelighed $«{ }^{66}$

66. Jacques Derrida: Spectres de Marx, Paris 1993, p. 160. 